\title{
羊毛の細胞間充填物およびヶラテインの銅イオン 共存による電子移動担体としての機能
}

\author{
福井大学工学部 田 畑 功 - 堀 照夫 - 中村 良治

\section{ELECTRON TRANSFER FUNCTION, IN THE PRESENCE OF CUPRIC IONS, OF THE INTERCUTICULAR CEMENT MATERIAL AND THE KERATEINE COMPONENT IN WOOL FIBER}

\section{By Isao Tabata, Teruo Hori, and Yoshiharu Nakamura}

Department of Applied Chemistry and Biotechnology, Faculty of Engineering,

Fukui University, Bunkyo, Fukui, 910 Japan

\begin{abstract}
Regarding the electron transfer function of the intercuticular cement material $(\delta)$ and of the kerateine component (RK) of wool in the presence of cupric ion, cyclic voltammetry of aq. mixed solutions of methylviologen (MV) and various amino acid-cupric complexes were carried out on a bare carbon electrode. Cyclic voltammetry of MV aq. solution was also done using electrodes modified with $\delta-\mathrm{Cu}^{2+}$ and $\mathrm{RK} \cdot \mathrm{Cu}^{2+}$. The occurrence of electron exchange between $\mathrm{MV}^{+}$and cupric complex of basic amino acid (His and Arg) and of $\delta$ or RK was evidenced. These suggest that the electron transfer function of $\delta$ and RK results from the shift of the standard redox potential of $\mathrm{Cu}^{2+} / \mathrm{Cu}^{+}$to more negative values by forming cupric complex with His and Arg residues in polypeptides of $\delta$ and that the cysteine residue in RK could also function as an electron carrier.
\end{abstract}

(Received February 5, 1990)

\section{1. 緒 言}

羊毛繊維は細胞の集積体からなること，拉よびその構 成ポリペプチドにシスチン残基が多く含まれることに特 徵がある。シスチン残基は羊毛の成長過程においてシス テインの酸化により形成されるが、これに関し緗胞間充 墳物 $(\delta)$ が電子移動担体 (EC)として閶与することが先の 研究によって明らかにされた[1]。また、些毛から抽出

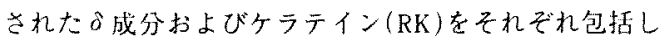
$\mathrm{Cu}^{2+}$ イオをドープした膜を介して，メチレンブルー (MB)のチオグリコール酸(TGA)による還元の進むこと が見出された[2]。一カ，Burley(3) は銅が欠そした飼 料で生育した羊から刈り取った羊毛の低い機械的强度を 説明するため，システインおよげシスチン含量を調べた 続果，强度を高めるシスチン含量が少ないことを見いた した。この事实は銅イオンが羊毛のケラチン化過程に， すなわち，上記電子伝達に密接に関与している可能性が あることを意昧している。 なお、へムタンパクの酸素連搬機能が代表するよう
に，生体内のタンパクー金属錯体が生体の生命維持にお いて重要に機能することはよく知られた事実でする。特 にタンパター金属錯体の電子伝達機能については，千卜 タローム鉄[4] やプルー銅タンパク[5]について詳細に 研究されており，後者ではメチオニンやシステインの1 オウとヒスチジンの塋素が銅イオンに配位してレドック ス友地に関与していることが見いたされれている。

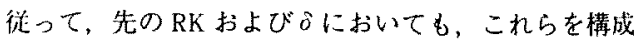
するポリペプチドのアミノ酸残基と銅との錯体が電子伝 详活性点となり EC 機能が生じていると推測できる。そ こで本研究では，はじめにモデル実驗として、種々のア ミノ酸一銅錯体と還元体メチルビオロゲン(MVさ)との間 の電子交换性をサイクリックボルタンメトリー(CV)法 により調べ，ついで親水性 $\delta\left(\delta_{\mathrm{n}}\right)$ と錩イオンを含む溶 液，または疎水性 $\delta\left(\delta_{\mathrm{L}}\right)$ またはRKと銅イオンとを表面 に修飾させた電楆を用いて，同様に $\mathrm{MV}^{\dagger}$ との電子交換 性を調べた。その結果, 一部の塩基性アミノ酸一銅錯 体，および $\delta$ 銅錯体が MV†から電子を受け取り，再生 された $M V^{2+} か ゙$ 再び電解還元されるという，いわゆる 
turnover 挙動が生じることを見いだした。本報では， これらの現象およびそれに基づいて羊毛の電子伝達機能 の発現を検討する。ここで，MVをメディエータとして 用いたのはこれが CVにおいて可逆的レドックス波を 生じること，およびその標準酸化還元電位が TGA/T. $\mathrm{GA}_{\mathrm{OX}}$ のそれより若干賁に大きく，上記膜を介しての MBの TGAによる還元過程のモデル䒺を構成し得るこ とによる。

\section{2. 実験}

\section{1 試 菜}

メチルビオロゲン (MV)，グリシン(Gly)およびL塩 基性アミノ酸としてのヒスチジン(His)，アルギニン (Arg)，およびリジン(Lys)はナカライテスク社製特級 試薬を用いた。その他の試薬もすべて市販品の特級試薬 をそのまま使用した。

\subsection{8 およびケラテイン成分の調慗}

羊毛の細胞間无填物の $\delta$ 成分 $\left(\delta_{\mathrm{L}}, \delta_{\mathrm{H}}\right)$ およびケラテ イン成分の抽出は，前報[2]に染じメリノ羊毛64'sを用 いて行った(スキーム1)。また $\delta_{\mathrm{H}}$ の比較として毛昽か ら抽出した nonkeratinous プロテイン(NKP)[6] も試料 とした。

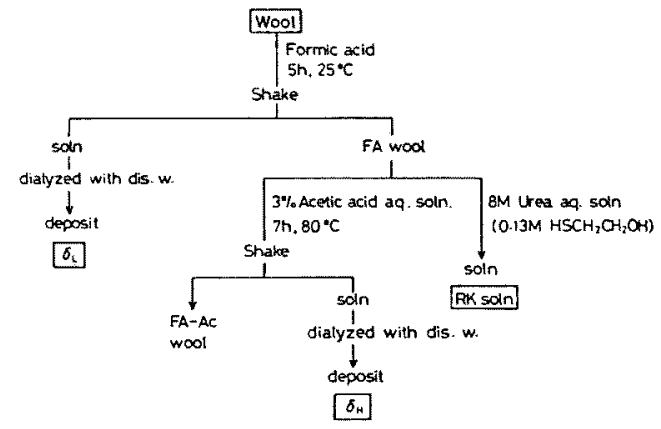

Scheme 1 The procedure for the extraction of $\delta$ and RK components from wool fiber.

\section{3 侮飾龟桠の作成}

作用電極の先端表面に $1 \% \mathrm{RK}$ 尿素溶液または $1 \% \delta_{\mathrm{L}}$ キ酸溶液を付着させ、これを0.5M K $\mathrm{KH}_{2} \mathrm{PO}_{4}$ 水溶液に静 かに漫漬することにより RK または $。$ を沈着させ，RK 修飾電極および $\delta_{\mathbf{L}}$ 修飾電極を作成した。次に $\mathrm{Cu}^{2+}$ イ ンを吸着させるだか,これらの修飾電極を0.5 $0 \mathrm{M} \mathrm{CuSO}_{4}$ 水溶液に10分間浸漬した後水洗した。これらを。 $\mathrm{RK}-\mathrm{Cu}^{2+}$ 修飾電極拈よび $\delta_{\mathrm{L}}-\mathrm{Cu}^{2+}$ 修飾電極とする。

\section{$2.4 \mathrm{CV}$ 測定装置及び㣜定来件}

\subsection{1 装}

サイクリックボルタモタラム(CV グラム)の作成には
ポテンショスタット(北斗電工 HA301)およびファンタ ションジェネレータ(北斗電I HB104) 用いた。作用 極，対極および參照電極には，それぞれグラッシカーボ ン (GC)電極(ヤナコスペック， $\phi=3 \mathrm{~mm}$ )，白金線扛よ び飽和カロメロ電極を用いた。

\section{4 .2 末倍飾電㮔での測定}

未修飾 $\mathrm{GC}$ 電極を用いて溶液系での CV 測定を行っ た。測定液は、アミノ酸 $-\mathrm{Cu}^{2+}-\mathrm{MV}$ 混合水溶液执よび 親水性ポリペプチド- $\mathrm{Cu}^{2+}-\mathrm{MV}$ 混合水溶液の 2 系列

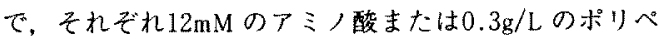
プチドと $1 \mathrm{mM} の \mathrm{Cu}^{2+}$ 抢よび0.5mMの MV，さらに支 持塩として0.5 $\mathrm{M} \mathrm{Na}_{2} \mathrm{SO}_{4}$ 艺含む。また，水酸化銅の生成 を避けるため，混合液は $\mathrm{H}_{2} \mathrm{SO}_{4}$ で $\mathrm{pH} 4.0$ に調整し $\mathrm{N}_{2}$ ガス通気により十分除酸素を行い測定した。な㧍，掃引 速度依存性を調べるため，掃引速度を10-500 $\mathrm{mV} / \mathrm{s} の$ 䈣围で変化させた。

\section{4 .3 修部電極での測定}

RK または $\delta_{\mathrm{L}}$ 修飾電極を用いた測定は， $1 \mathrm{mM} の \mathrm{MV}$

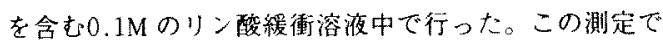
は， $\mathrm{NaOH}$ で測定液を $\mathrm{pH} 4.0-7.7$ に調整し，十分除酸 素した後測定した。ここでの掃引速度は，すべて $50 \mathrm{mV} / \mathrm{s}$ としだ。

\section{3. 結果および考察}

\section{1 アミノ酸 $-\mathrm{Cu}^{2+}-\mathrm{MV}^{2+}$ 混合水溶液の $\mathrm{CV}$}

MVは式 1 に示すような 2 段階のレドックス反即を起 こすことが知られている[7]。

$$
\begin{aligned}
& \mathrm{MV}^{2+}+\mathrm{e} \underset{\mathrm{N}}{\stackrel{\mathrm{I}}{\rightleftarrows}} \mathrm{MV}^{+} \\
& \mathrm{MV}^{+} \stackrel{\text { II }}{\underset{\mathrm{II}}{\rightleftarrows}} \mathrm{MV}^{0}
\end{aligned}
$$

本研究で用いた未修飾 GC 電極での MV の CV 明線を図 1 は亦。

图 2 には $\mathrm{Cu}^{2+}$ 単独抢よび各アミノ酸過剩存在下での $\mathrm{Gly}-\mathrm{Cu}^{2+}$ 錯体抢よび His-Cu ${ }^{2+}$ 錯体の CV 曲線を示す。 これらは，掃引回数に伴う波形の变化が生じなくなる第 6 掃引での曲線である。いずれの場合も， $\mathrm{Cu}^{2+}$ とアミ ノ酸の䦎で錯体を形成すると $\mathrm{Cu}^{2+}$ の第 1 還元䉓位が真 にシフトし，特にHis-Cu ${ }^{2+}$ 錯体でそれが著しいこの還 元電位のシフトは，アミノ酸が1洒の銅とよりも2 価の 銅と、より安定な錯体を形成するだ，錯体中の $\mathrm{Cu}^{2+}$ が $\mathrm{Cu}^{+} に$ 遷元されにくくなることによる(8])。

図 3 は, アミ/酸 $-\mathrm{Cu}^{2+}-\mathrm{MV}^{2+}$ 混合水溶液の1.0 $-1.5 \mathrm{~V}$ vs. SCE の広い電位幅で測定した第 6 掃引の CV グラムである。曲線は，MVの4つのレドックス波にア 


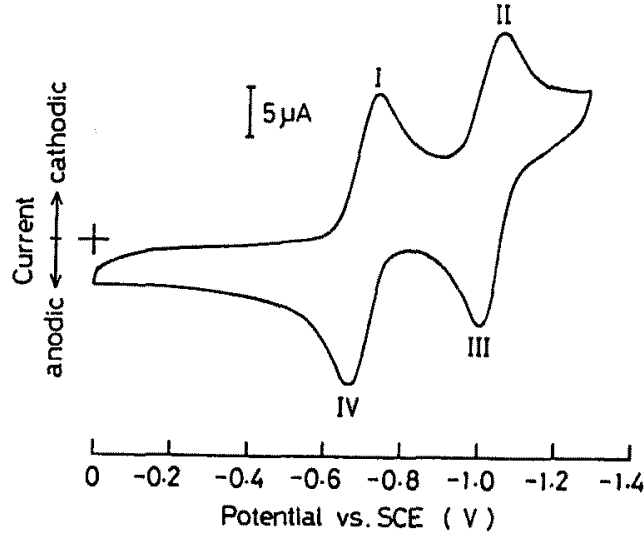

Fig. 1. A cyclic voltammogram of $\mathrm{MV}$ using the bare GC electrode. $1 \mathrm{mM} \mathrm{MV} \mathrm{MV}^{2+}$ in $0.1 \mathrm{M}$ phosphate buffer aqueous solution at $\mathrm{pH} 7.0$. Scan rate, $200 \mathrm{mV} \cdot \mathrm{s}^{-1}$.

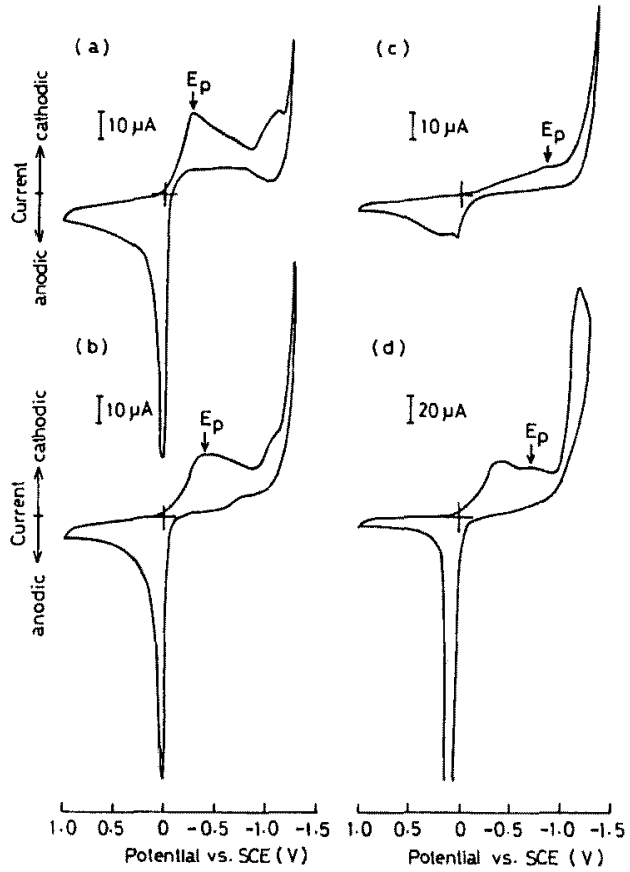

Fig. 2. Cyclic voltammograms of amino acid. $\mathrm{Cu}^{2+}$ complexes by using the bare $\mathrm{GC}$ electrode, $1 \mathrm{mM} \mathrm{Cu}^{2+}$ and $12 \mathrm{mM}$ amino acid in $0.5 \mathrm{M} \mathrm{Na}_{2} \mathrm{SO}_{4}$ aqueous solution at pH 4.0. Scan rate: (a) - (c), $50 \mathrm{mV} \cdot \mathrm{s}^{-1}$; (d), $200 \mathrm{mV}$. $s^{-1}$. (a) $\mathrm{Cu}^{2+}\left(\mathrm{E}_{\mathrm{p}}=-0.30 \mathrm{~V}\right.$ vs. SCE); (b) Gly $\mathrm{Cu}^{2+}\left(\mathrm{E}_{\mathrm{p}}\right.$ $=-0.40 \mathrm{~V}$ vs. SCE); (c) His.Cu ${ }^{2+}\left(E_{\mathrm{p}}=-0.84 \mathrm{~V}\right.$ vs. SCE); (d) $\mathrm{Arg}_{-} \mathrm{Cu}^{2+}$ (2nd $\mathrm{E}_{\mathrm{P}}=-0.70 \mathrm{~V}$ vs. SCE).

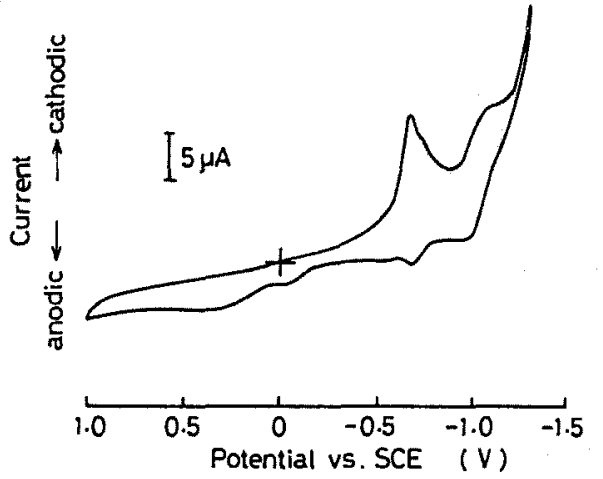

Fig. 3. A cyclic voltammogram of aq. mixed solution of $\mathrm{MV}^{2+}$ and His- $\mathrm{Cu}^{2+}$ complex on the bare GC electrode obtained at the 6 th scan. Scan rate $50 \mathrm{mV} \cdot \mathrm{s}^{-1}$.

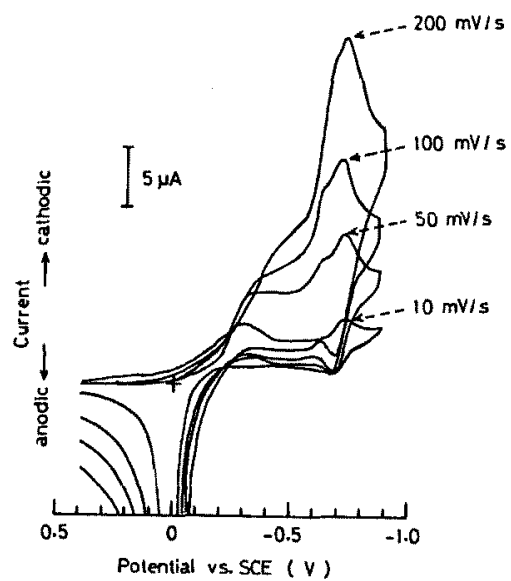

Fig. 4. The scan rate dependence of cyclic voltammo. gram for aq. mixed solution of $\mathrm{MV}^{2+}$ and $\mathrm{His} \cdot \mathrm{Cu}^{2+}$ complex obtained at the 1 st scan.

ミノ酸-Cu ${ }^{2+}$ のレドックス波が加わり複雑であるが, MV の第 1 還元波（I）に相当する波が特に大きいことが 分かる。このI波の增大をより詳細に調べるため, $+0.4 \sim 0.9 \mathrm{~V}$ vs. SCE の電位幅で単掃引法での CV ダ ラムを種々の掃引速度で測定した。 $\mathrm{His}^{-} \mathrm{Cu}^{2+}-\mathrm{MV}^{2+}$ 系 で得られた CV ダラムを図 4 に示す。単掃引では、負電 位方向への掃引でまずアミノ酸-銅錯体の第 1 還元波が 現れ，続いて MV の第 1 還元波が生ずる。これらの CV グラムから錯体のみの CV グラムを用いて錯体のレドッ クス波を差し引き，MVのI波とIV 波の正味のピーク 電流 $\mathrm{I}_{\mathrm{P}}$ を算出した。通常 $\mathrm{I}_{\mathrm{P}}$ はレドックス活性種の拡散 係数 $\mathrm{D}$ と掃引速度 $\mathrm{v}$ との間に

$\mathrm{I}_{\mathrm{P}} \propto(\mathrm{Dv})^{1 / 2}$

の関係がある(12)，これらの $\mathrm{I}_{\mathrm{P}}$ を $\mathrm{v}^{1 / 2} に$ 対しプロットし 

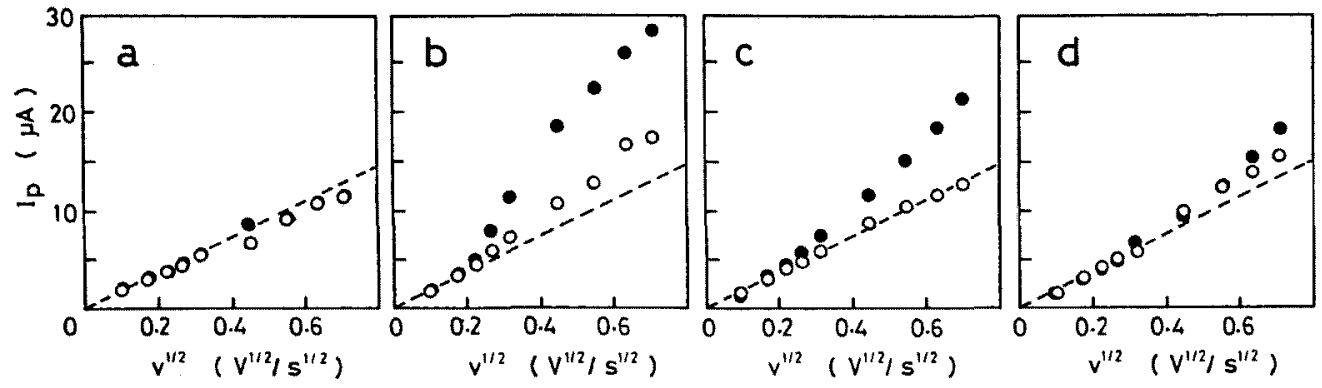

Fig. 5. Effect of scan rate on the peak current of $M V$ waves in the presence of amino acid $\mathrm{Cu}^{2+}$ complex. Bare GC electrode was used. . O : obtained for the 1 st reduction wave of $\mathrm{MV}^{2+}(\mathrm{I}$ in Fig. 1) and the 2 nd oxidation wave of $\mathrm{MV}^{0}$ (V in Fig. 1). a, Gly $\cdot \mathrm{Cu}^{2+} ; \mathrm{b}$, His $\cdot \mathrm{Cu}^{2+} ; \mathrm{c}, \mathrm{Arg} \cdot \mathrm{Cu}^{2+} ; \mathrm{d}, \mathrm{Lys} \cdot \mathrm{Cu}^{2+}$.

たのが図 5 である。ここで，図中の点線はアミ/酸を含 まないMV 溶液の場合であり，直線関係の得られたこ とから应散支配であることが分かる。さらに，4種のア ミノ酷一銅錯体試料のうち, $\mathrm{His}-\mathrm{Cu}^{2+}$ および $\mathrm{Arg}-\mathrm{Cu}^{2+}$ では，掃引速度が速いほどMVの第 1 還元波を增大さ せることが分かる。このような特定のアミノ酸による MV 第 1 還元波の増大とその掃引速度依存性を, 次のよ うに解釈した。

図 4の His $\mathrm{Cu}^{2+}$ 錯体の例から分かるように，最初に 現れるアミ，酸一銅錯体の第 1 還元波は，掃引速度の増 大とともに負の電位にシフトする。このため MVの第 1 還元が生ずる電位では，掃引速度が速いほど電極表面 における末僄元のアミノ酸一銅錯体が多く存在するよう になる。この未還元銅錯体上電解還元で生したMVさと がスキーム2のような電子交換反応を起こし、この $\mathrm{MV}^{2+}$ の turnoverによりI波の增大が生じたものと言え b。

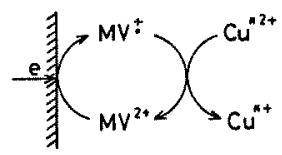

Scheme 2 A schematic view of electron exchange between $\mathrm{MV}^{+}$and amino acid-cupric complex on bare electrode.

一方，Gly扔よびLys のCu ${ }^{2+}$ 錯体でもこのような掃 引速度の増大に伴う還元波のシフトが見られたが，これ らの錯体では $\mathrm{MV}^{2+} へ の$ turnover は生じない。この現 象を説明するため，図 2 の波形安定後の CV グラムから 得られる各錯体の還元電位とMVの第 1 還元電位を比 較すると， $\mathrm{Gly}-\mathrm{Cu}^{2+}$ の遭元電位は負にシフトするとは 言え，MV $\mathrm{V}^{2+}$ のそれよりもかなり正側に位置しているこ とが分かる。また Lys $-\mathrm{Cu}^{2+}$ 錯体の還元電位も $\mathrm{Gly}^{-\mathrm{Cu}^{2+}}{ }^{2}$ 錯体のそれと同程度であった。従って，これ
Table 1 Composition Ratio and Stability Constant of Various Amino Acid. $\mathrm{Cu}^{2+}$ Complexes

\begin{tabular}{lcc}
\hline Amino acid & Molar ratio to $\mathrm{Cu}^{2+}$ & Stability constant, $\log \beta$ \\
\hline Gly & 2 & $14.87^{(9)}\left(\mu=0.1,25^{\circ} \mathrm{C}\right)$ \\
His & 2 & $18.53^{(10)}\left(\mu=0.5,25^{\circ} \mathrm{C}\right)$ \\
Lys & 2 & $13.90^{(11)}\left(\mu=0.1,25^{\circ} \mathrm{C}\right)$ \\
\hline
\end{tabular}

らの錯体は $\mathrm{MV}^{2+}$ が還元される電位では直接電解還元を 受けるため，MV゙から電子を受け取る機会が少ない。

一方, $\mathrm{Arg}-\mathrm{Cu}^{2+}$ 錯体の第 1 僈元電位は $50 \mathrm{mV} / \mathrm{s}$ の掃 引速度では图 2 の $\mathrm{Gly}-\mathrm{Cu}^{2+}$ と同程度であったが, $200 \mathrm{mV} / \mathrm{s}$ の速い掃引速度で測定すると的 $-0.70 \mathrm{~V}$ vs. SCEの電位に錯体による新たなと゚ータが現われる(図 2. d)。これより， $\mathrm{Arg}-\mathrm{Cu}^{2+}$ 錯体は掃引速度の堌大と共に 還元電位が負へシフトし，直接電解還元を受けるよりも $\mathrm{MV}^{\dagger}$ と電子交換を行なう方が容易になると言える。

さらに，表1に示した各アミノ酸一銅錯体の安定度定 数を比較すると， $\mathrm{MV}^{2+}$ ○の turnover 誘起した $\mathrm{His}-\mathrm{Cu}^{2+}$ 錯体が最も安定な錯体を形成することが分か り，また安定度定数が不明の $\mathrm{Arg}-\mathrm{Cu}^{2+}$ 錯体も構造上か なり安定であることが期待され，以上の考察が妥当と言 える。なお，図2の(c)に示されるように His-Cu $\mathrm{Cu}^{2+}$ 錯体 の場合酸化波も小さいが，これはこの錯体の高い安定性 のため遊離の銅イオンの量が少ないこと，および遙元電 位の著しい夐へのシフトのため第 2 還元による0洒の銅 までの還元が進行していないことによると考えられる。

\section{2 親水性ポリペブチドーCu $\mathrm{Cu}^{2+}-\mathrm{MV}^{2+}$ 混合溶液の CV}

アミノ酸の代わりに $\delta_{\mathrm{H}}$ また NKP を溶解して調製し た親水性ボリベプチドーCu${ }^{2+}-\mathrm{MV}^{2+}$ 混合溶液での $\mathrm{MV}$ 第 1 波の $\mathrm{I}_{\mathrm{P}}$ の授引速度依存性を図6に示した。 $\delta_{1}$ 点 む系ではHisの場合と同様な $\mathrm{I}_{\mathrm{P}}$ の增大が見られるが, NKP ではこの增大はわずかである。この相違は, 雨ぺ 


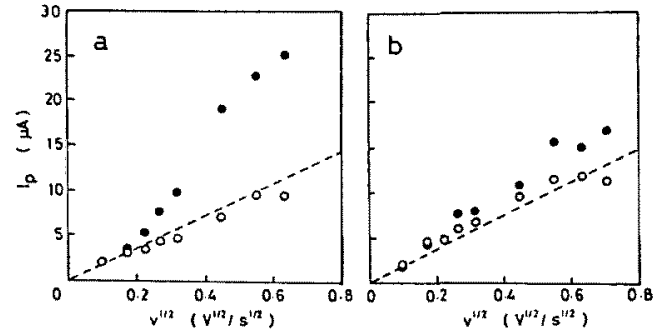

Fig. 6. Effect of scan rate on the peak current of MV waves in the presence of $\delta_{\mathrm{H}} \mathrm{Cu}^{2+}$ (a) and NKP.Cu${ }^{2+}$ (b). Bare GC electrode was used. $O$ : obtained for the 1 st reduction wave of $\mathrm{MV}^{2+}$ ( $\mathrm{I}$ in Fig. 1 ) and the 2nd oxidation wave of $M V^{\circ}(\mathrm{N}$ in Fig. 1).

Table 2 Amino Acid Content of the $\delta$ Components in Wool and the Nonkeratinous Protein in Human Hair

\begin{tabular}{lrrr}
\hline Amino Acid & \multicolumn{1}{c}{$\delta_{L}$} & $\delta_{\mathrm{H}}$ & NKP \\
\hline Nonpolar & 50.4 & 46.1 & 66.5 \\
Basic & 9.1 & 12.5 & 7.1 \\
Lys & 2.9 & 2.5 & 2.7 \\
His & 1.0 & 1.9 & 1.5 \\
Arg & 5.2 & 1.9 & 1.5 \\
Acidic & 14.1 & 12.5 & 15.0 \\
Polar & 25.1 & 26.5 & 11.4 \\
1/2 Cys & 1.3 & 2.4 & 0 \\
\hline
\end{tabular}

in $\mathrm{mol} \%$

プチドを構成するアミノ酸残基の相違によるものと考え られる。そこで，これらのペプチドのアミノ酸分析結

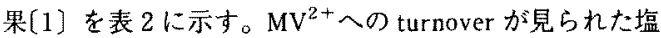

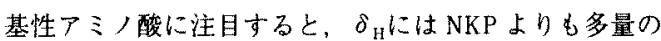
Arg が拿まれることが分かり，この Arg 残基と $\mathrm{Cu}^{2+}$ と の錯体が MV のI波の増大に寄与していた可能性が大き Wo

\section{$3.3 \mathrm{RK} / \delta_{L}$ 倍飾電極による MVの CV}

図 $7 に \mathrm{RK}-\mathrm{Cu}^{2+}$ 修飾電極を用いて $\mathrm{pH} 7.0 て ゙$ 測定した $\mathrm{MV}^{2+}$ 水溶液の CV 曲線を示す。第 1 掃引では MV の第 1 還元波の著しい増大が見られるが，第 2 掃引以後この 増大はほとんど見られない。しかし，測定後この電極を $1 \mathrm{~V}$ で10分間保持した後再測定すると図8のようにMV の】波の増大が再現した。一力新たに作成した $\mathrm{RK}-\mathrm{Cu}^{2+}$ 修飾電極を用いて $\mathrm{MV}^{2+}$ を含まないブランク 水溶液中で測定したCVグラムには，ほとんどレドック ス波が現れないことから，この MVのI波の增大は単に $\mathrm{RK}-\mathrm{Cu}^{2+}$ の還元波が加算されて生じたものではない。 $こ の \mathrm{MV}$ のI被の増大の原因を調べるため、 $\mathrm{pH} 4.0-$

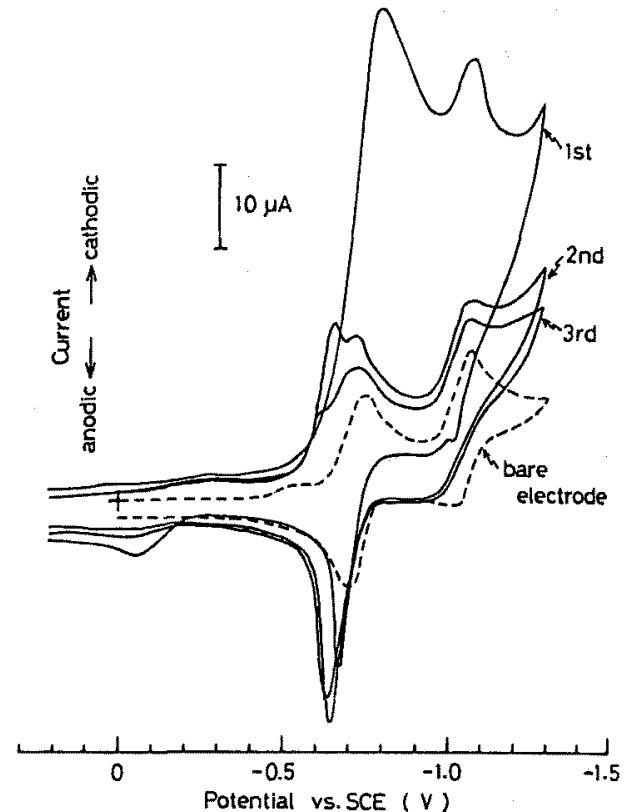

Fig. 7. Cyclic voltammograms of $1 \mathrm{mM} \mathrm{MV} \mathrm{MV}^{2+}$ solution using the RK. $\mathrm{Cu}^{2+}$ modified $\mathrm{GC}$ electrode at $\mathrm{pH} 7.0$. Broken line is for an unmodified $\mathrm{GC}$ electrode.

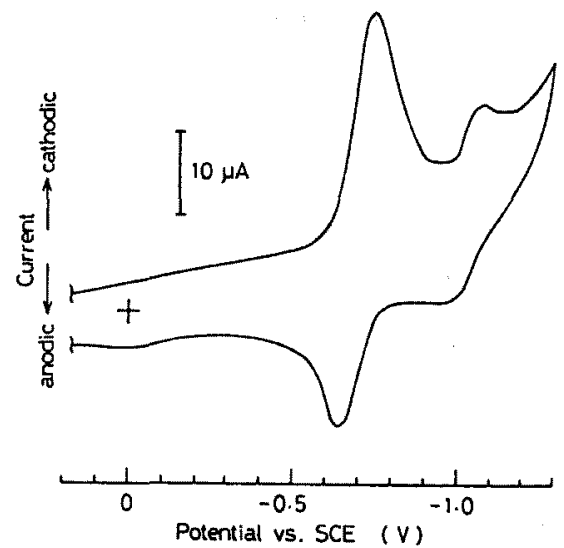

Fig. 8. Reproduction of 'MV turnover' after keeping the electrode used in the experiment in Fig. 7 at $1.0 \mathrm{~V}$ for $10 \mathrm{~min}$.

7.70 範讲で $\mathrm{pH}$ を変化させ $\mathrm{RK}$ 修飾電極および $\mathrm{RK}-\mathrm{Cu}^{2+}$ 修飾電極で MV の CV 曲線を測定した。得ら

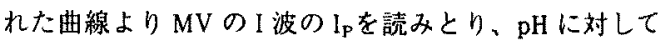
プロットしたのが図 9である。破線は末修飾電極での結 果である。

$\mathrm{RK}-\mathrm{Cu}^{2+}$ 修飾電極では $\mathrm{pH} の$ 増大に伴い $\mathrm{I}_{\mathrm{p}} か ゙$ 増大し、 pH7.0以上でほほ一定となる。この pH 依存性は，恐ら 


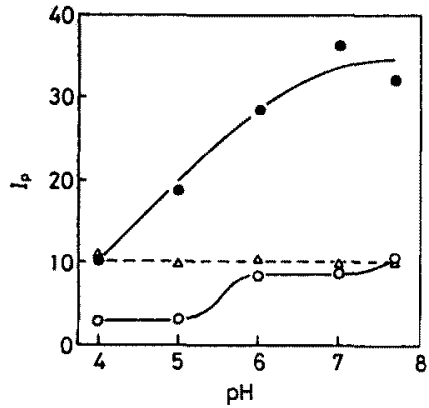

Fig. 9. Dependence of the peak current of the 1st reduction wave $\mathrm{I}$ on $\mathrm{pH}$ for the $\mathrm{RK}$ modified $\mathrm{GC}$ ele.

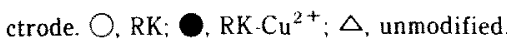

く RKを構成するアミノ酸残基と銅との錯体の形成が $\mathrm{pH}$ が高いほど進行するために生ずると思われる。すな わち $\mathrm{pH}$ が高い程アミ八酸残基に配位結合する $\mathrm{Cu}^{2+}$ イ オンの量が増大し，スキーム2で示したような電子交換 反応が一層進行すると推測される。またこの turnover が第 2 掃引以降見られないことから，一度銅イオンが還 元体になると，連続掃引時の短い電解酸化では容易に酸 化体に戻れず，MV士の再酸化に関与できなくなるよう である。しかし，pH7.0以上ではその後の電極の $1 \mathrm{~V}$ 保 持により turnover が再現され、この銅錯体の還元体は 電極反応により酸化体に戻ることが分かった。

一方 RK 修飾電楆では $\mathrm{pH}$ が低くなるに従い MVのI 波の $\mathrm{I}_{\mathrm{P}}$ が小ざくった。これれは測定液が酸性になるに 従いタンパク中のアミ，酸残基のうちプロトン化してい るものが增大し，この正の電荷により電極表面屡に MV๋が近づきにくくなるためと解粕できる(未修飾電極 では $\mathrm{pH} 4$ でも MVのI波のI $I_{\mathrm{P}}$ 值の低下は見られないー 図 9 破線)。

なお，图7のようにMVのN 波に相当する酸化波も 大きくなっている。この酸化波の增大は RK 修飾電極を 用いた場合も生じることより，銅錯体によるものではな く RK 自身とMV との相互作用によるもので[1]，スキ 一ム3のようにRKの構成アミノ酸システインから $\mathrm{MV}^{2+}$ 一電子が渡されるた好と考えられる。

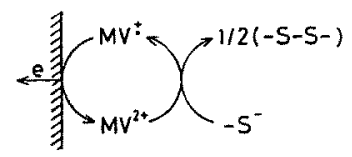

Scheme 3 A schematic view of the electron exchange reaction on the RK modified electrode.

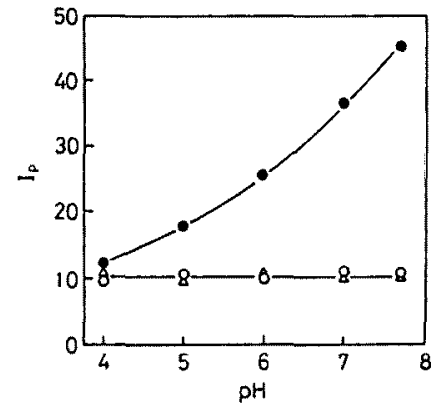

Fig. 10. Dependence of the peak current of the 1 st reduction on $\mathrm{pH}$ for the $\delta_{\mathrm{L}}$ modified $\mathrm{GC}$ electrode. $\mathrm{O}$. $\delta_{\mathrm{L}}$ ○. $\delta_{\mathrm{L}} \cdot \mathrm{Cu}^{2+} ; \Delta$, unmodified.

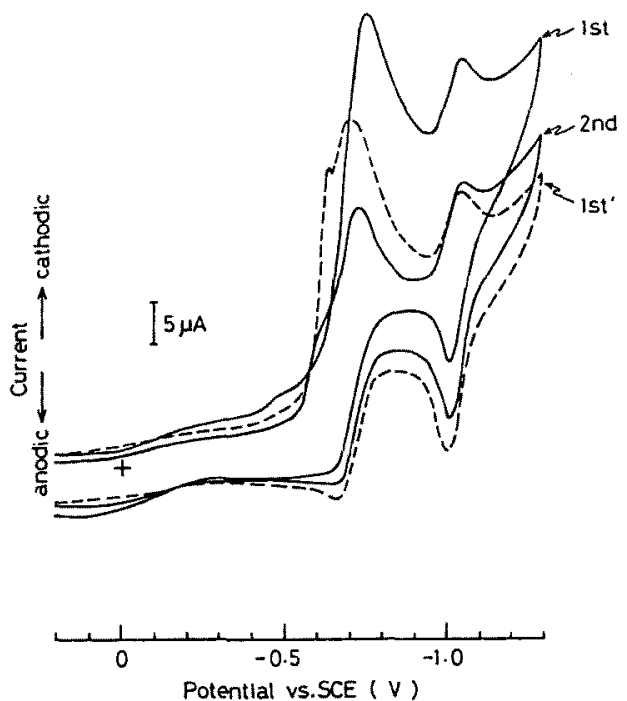

Fig. 11. Cyclic voltammograms of $1 \mathrm{mM} \mathrm{MV}^{2+}$ solution using $\delta . \mathrm{Cu}^{2+}$ modified $\mathrm{GC}$ electrode at $\mathrm{pH} 7.0$. Broken line, after keeping the tested electrode at $1.0 \mathrm{~V}$ for 10 $\min$.

$\delta_{L} お よ ひ ゙ \hat{o}_{\mathrm{L}}-\mathrm{Cu}^{2+}$ 修飾電極についても同様な $\mathrm{CV}$ 湘 定を行なった。種々の $\mathrm{pH}$ で測定した第 1 掃引に扔ける $M V$ の第 I 波の $I_{P}$ を图10に示す。また，一例として $\mathrm{pH} 7.7$ での $\delta_{\mathrm{L}}-\mathrm{Cu}^{2+}$ 修飾電極による CVグラムを図11に 示す。 $\mathrm{RK}$ と同様 $\mathrm{Cu}^{2+}$ を吸着することで $\mathrm{pH}$ の增大に伴 う I 波の增大が見られ、その後の $1 \mathrm{~V}$ の電位保持による I波增大の復元も見ら机た。於を構成するアミノ酸残基 を調べると、表 2 に示すように塩基性アミノ酸のうち $\operatorname{Arg}$ が比較的多いので，この Arg 残基と銅との錯体と MV†とが電子交換し，I波の增大をもたらすと考察でき る。一方，銅を含ま好系ではRKで見られたような夕ン パク自体が直接関与するMVのレドックス反応は見ら 
れなかった。これは，ठににはシステインが殆ど含まれ ないためである。

\section{4 銅吸着 RK $/ 8$ の電子移動坦体としての機能の評価} $\mathrm{RK}-\mathrm{Cu}^{2+}$ または 0 - $\mathrm{Cu}^{2+}$ を包括したウレタン膜を介し てのチオグリコール酸(TGA)によるメチレンブルー (MB)の還元退色実験加，これら膜中の担体に電子伝 達機能のあることを既に報告した[2]。このような担体 の電子伝達は、これらを構成するポリペプキドのアミ， 酸残基と銅との錯体が，スキーム4のようなレドックス

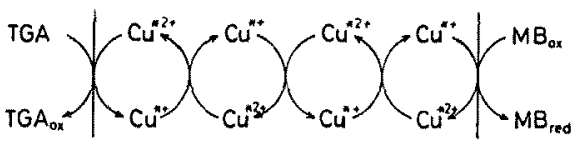

Scheme 4 A schematic view of electron transfer proces. ses across the $\delta / \mathrm{RK}$ immobilized and $\mathrm{Cu}^{2+}$ doped mem. brane.

サイクル連鎖を構成するためと推測される。この電子伝 達系に関連するレドックス種の $\mathrm{pH} 7$ での標準酸化逼元 電位 $\mathrm{E}_{0}{ }^{\prime}$ は, $\mathrm{TG} A_{\mathrm{OX}} / \mathrm{TGA}$ 系で $-0.401 \mathrm{~V}$ vs. NHE,

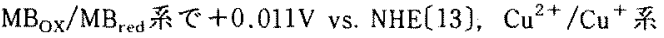
(非錯体)でー0.153V vs. NHE[14]であるが,これらの 值と CV 测定より確か女た His およびArg の配位による 銅のレドックス電位の負へのシフトを考慮すると、いず れのアミノ酸一銅錯体もTGA から電子を受け取れる が, MBへの電子授与については His およびArgの铜錯 体でのみ可能と言之る。従って， $\delta_{\mathrm{L}}-\mathrm{Cu}^{2+} ゃ \mathrm{RK}-\mathrm{Cu}^{2+}$ の電子伝達にはアミノ酸残基のうち Hisや $\mathrm{Arg}$ と銅と の錯体が関与していた可能性が大きい。さらにRKの場 合，銅不在下でもある程度電子伝達機機能があることか ら，システイン残基のジスルフィド交換反応（15]も関 与していることが考えられる。

\section{4. 結 論}

アミノ酸-銅錯体とMV との電子交換性を CV 法によ

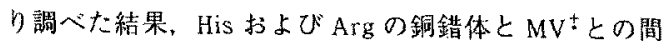
で電子交換が生じることを見いだした。さらに $\mathrm{RK}-\mathrm{Cu}^{2+}$ または $\delta-\mathrm{Cu}^{2+}$ 修飾電極による $\mathrm{CV}$ 測定によ ク, $\mathrm{pH}$ が高い程これらの修飾材と $\mathrm{MV}^{\ddagger}$ との間で電子交
換が生じやすくなることを見いだした。これらの電子交 換反応は，銅のレドックス䉓位が His や Argの配位に より負にシフトするために生じたもので，このシフトが 電子移動担体としての機能発現に必要であると結論し た。

\section{文献}

1. Y. Nakamura, K. Kosaka, T. Tada, K. Hirota, and T. Hori, Proc, 7th Int. Wool Text. Res. Conf. Tokyo, 1 , 171 (1985)

2. Y. Nakamura, M. Yamada, J. Miura, K. Hirota, and T Hori. J. Polym. Sci., Polym. Chem., 27, 2883 (1989)

3. R. Burley, Text. Res, J., 30, 473 (1960)

4. R. Bechtold, M. B. Gardineer, A. Kazmi, B. Hemelryck, and S. S. Isied. J. Phys. Chem. Soc., 90, 168 (1980)

5. E. I. Solomon. J. W. Hare, D. M. Dooley, J. H. Dawson, P. J. Stephens, and H. B. Gray, J. Am. Chem. Soc., 102, 168 (1980)

6. S. Kanetaka, K. Miyata, and Y. Nakamura, J. Soc Cosmet. Chem., Japan, 24, 5 (1990)

7. E. Steckhan and T. Kuwana, Ber. Bunsenges, Phys. Chem., 78, 253 (1974)

8. 域口武一,上野景平編；「金属キレート[I]」，南 江堂, p. 52 (1965)

9. D. L. Leusing and K. S. Bai, Anal. Chem., 40, 575 (1968)

10. M. A. Doran. S. Chaberek, and A. E. Martell, J. Am. Chem. Soc., 86, $2129(1964)$

11. S. Nyberg and M. Cefola, Arch. Biochem. Biophys., 111, 327 (1965)

12. R. S. Nicholson and 1. Shain, Anal. Chem., 36, 706 (1964)

13. 井村伸正，大鳥泰郎，黑川正則，永井克孝，三浦䔆 一郎，水島昭二編，「生化学ハンドブック」, 丸善, p. 356 (1984)

14. 日本化学会編, 「化学便覧 基礎編 II」, 丸善, p. 1205 (1975)

15. F. Sanger, Nature, 171, 1025 (1953) 